\title{
THE REDUCTION OF ANXIETY AND PAIN DURING VENOUS BLOOD SAMPLING USING HYPNO-EFT (EMOTIONAL FREEDOM TECHNIQUES) METHOD
}

\section{Diah Navianti*, Ardiya Garini, Karneli}

\author{
Department of Medical Laboratory Technology, Health Polytechnic of Palembang, Ministry of Health of the Republic of \\ Indonesia
}

\author{
Accepted: 1 June 2018 \\ *Correspondence: \\ Diah navianti \\ Department of Medical Laboratory Technology \\ Health Polytechnic of Palembang, Ministry of Health of the Republic of Indonesia \\ Jln. Sukabangun 1 Sukarame KM 6.5 Palembang, South Sumatera \\ E-mail : dnaviantidiah9@gmail.com
}

Copyright: ( $)$ the author(s), YCAB publisher and Public Health of Indonesia. This is an open-access article distributed under the terms of the Creative Commons Attribution Non-Commercial License, which permits unrestricted non-commercial use, distribution, and reproduction in any medium, provided the original work is properly cited.

\begin{abstract}
Background: Venous blood sampling has several risks of complication, the basic cause was emotional factor, such as anxiety and pain, which remain important to be solved.

Objective: The aim of this study was to determine the effect of hypno-EFT to reduce the anxiety and pain during venous blood sampling.

Methods: The design of the study was quasi experimental, with pretest posttest with control group design. The sampling technique was simple random sampling to select 52 respondents. Anxiety was measured using a Hamilton anxiety rating scale (HARS) modification and pain was measured using the Visual analogue scale (VAS) method. Wilcoxon and Manova multivariate test were used for data analysis.

Results: Before hypno-EFT there was 1 person (2.9\%) did not experience anxiety, 9 people $(25.7 \%)$ with mild anxiety, 20 people $(57.1 \%)$ with moderate anxiety and 5 people $(14.3 \%)$ with severe anxiety. After hypno-EFT therapy, there were 23 people $(65.7 \%)$ did not get anxiety, mild anxiety were 11 people $(31.4 \%)$ and severe anxiety was found in 1 person $(2.9 \%)$. For the average pain of respondent in venipuncture before hypno-EFT was 3.20 with a median 3.00 and a standard deviation was 1.91. The minimum value of pain was 0 and 9 in maximum. After therapy Hypno-EFT, the average pain was 1.54 and the minimum value of pain was 0 and 6 at maximum. Statistical result showed that the pvalue of anxiety and pain was $0.000(<0.05)$

Conclusion: There was a significant effect of hypno-EFT therapy to decrease the anxiety and pain during venous blood sampling. This method is recommended as an alternative procedure in venous blood sampling with complicating factors.
\end{abstract}

Keywords: Phlebotomy, Hypno-EFT, Palembang, Indonesia

\section{INTRODUCTION}

Phlebotomy is a routine process of blood sampling in laboratory and it should be done professionally. Therefore, a phlebotomist is expected to handle the situation according to guidelines based on their job (Pendergraph \& Pendergraph, 1998). There are several types of phlebotomy, one of them is venous blood sampling. It used larger syringe sizes and sharp needle. Blood sampling (venipuncture) requires particular technique and it must be done by profesional health workers because the venous blood sampling is important (Booth, 
Wallace, \& Fitzgerald, 2009). Venous blood sampling has several risks of complication. There are some complications of blood sampling. One of them caused by physiological or medical factor such as syncope (fainted). The most factor of syncope is emotional factors such as nervous, pallor and anxiety (Booth et al., 2009).

The feeling of nervous, pallor and anxious can be referred as anxiety. This anxiety arises from lack of unexplained knowledge and fear, a worry, no specific object, and it is subjective (Stuart \& Sundeen, 2007). It takes a way to lower anxiety and pain in venous blood sampling. This reduction must be done by providing a comfort situation to patients so the syncope would not happen during venous blood sampling.

Anxiety and pain reduction can be done by pharmacological and non-pharmacological therapy. Non-pharmacological interventions need to be developed, related to the psychological problems that affected by anxiety and pain problems. The development of non pharmacologic therapy has also evolved to complementary therapies. People choose this therapy based on the low side effects (van der Watt, Laugharne, \& Janca, 2008).

Hypnosis is one of the conscious conditions where people are able to accept the suggestions (information). Hypnosis also defined as the optimal condition of the subconscious mind or critical area (Nurindra, 2007). Based on the principles of human behavior $88 \%$ by sub-conscious and new values can be implanted in the sub-conscious through the Hypnosis process. This hypnosis process can be used for the initial process of venous blood sampling in patients to reduce the pain. The early phase of hypnosis is preinduction phase (early process before the actual hypnosis session) (Nurindra, 2007).

Emotional freedom technique (EFT) is a complementary therapy developed by Gary Craig. EFT is a non invasive action and part of emotional acupressure based on energy power of acupunture. It was developed to manage stress and anxiety (Prameswari \& Ariyani, 2015). EFT has proved and able to treat a lot of problems. Through the research of holistic hypnotherapy modification, it has been found that negative thoughts and emotions come from the subconscious mind. By this method, people are directed to be positive thinking. Other researh showed that the hypno EET method can reduce stress and anxiety (Iskandar, 2010; Temple \& Mollon, 2011; van der Watt et al., 2008).

An early study in Medical Laboratory Technology of Health Polytechnic of Palembang showed that $42 \%$ of students had anxiety and $34 \%$ of students got pain during venous blood sampling. In every year at phlebotomy class or practice of venous blood sampling found that $5 \%$ students were fainted during the class. The aim of this study was to determine the effect of hypno - EFT to reduce the anxiety and pain during venous blood sampling. This research was conducted by observing anxiety and pain during venous blood sampling.

\section{METHODS}

\section{Study design}

This was a quasi-experimental study with pretest posttest with control group design.

\section{Sample}

Population of this research were all students in SMAN 22 Palembang. The technique sampling was simple random sampling. The total sample of the research was 35 students for a treatment group and 17 students in a control group.

\section{Intervention}

The researchers did intervention to both of groups. The control group was intervented by venous blood sampling for 2 - 3 minutes, while the treatment group was intervented by giving the hypno-EFT method and standard phlebotomy procedure for 4-5 minutes. Measurement of anxiety and pain was done before and after intervention in both groups. 


\section{Instrument}

Anxiety and pain were measured in this study. The anxiety of respondents was measured by using the HARS Modified Questionnaire. It is a standard questionnaire which consist of 25 questions to measure anxiety of respondent. Meanwhile, the pain was measured by Visual Analogue Scale (VAS) Tool, with a line span of 10 centimeters (Nursalam, 2008; Yudiyanta \& Novitasari, 2015).

\section{Ethical consideration}

Ethical approval was obtained from the Health Research Ethics Commission at Health Polytechnic of Makassar. The researcher explained the objectives and procedures of the study, and asked for the subject's willingness to be the respondent in the study and asked participants to sign the informed consent.

\section{Data analysis}

Wilcoxon signed rank test was used for data analysis because the result of normality test using Kolmogorov smirnov was $<0.05$, which indicated that the data were not in normal distribution. In multivariate test after analysis between treatment group and control group, normal and homogeneous distribution data were obtained, then the analysis was continued to multivariate test of Manova (Kuzma \& Bohnenblust, 1992).

\section{RESULTS}

Table 1 about the distribution of anxiety before intervantion of treatment group showed that 1 person $(2.9 \%)$ had no anxiety, mild anxiety was found in 9 people $(25.7 \%)$, moderate anxiety in 20 people $(57.1 \%)$, and severe anxiety in 5 people $(14.3 \%)$. Meanwhile after treatment, 23 people $(65.7 \%)$ with no anxiety, mild anxiety in 11 people $(31.4 \%)$ and severe anxiety in 1 person $(2.9 \%)$.

Table 1 Frequency distribution of respondent's anxiety before and after hypno-EFT therapy during venous blood sampling

\begin{tabular}{|c|c|c|c|c|}
\hline \multirow{3}{*}{$\begin{array}{l}\text { Anxiety } \\
\text { Before } \\
\end{array}$} & \multicolumn{4}{|c|}{ Group } \\
\hline & \multicolumn{2}{|c|}{ Treatment } & \multicolumn{2}{|c|}{ Control } \\
\hline & Total & Percentage & Total & Percentage \\
\hline No anxiety & 1 & 2.9 & 3.0 & 17.6 \\
\hline Mild anxiety & 9 & 25.7 & 12.0 & 70.6 \\
\hline Moderate anxiety & 20 & 57.1 & 1.0 & 5.9 \\
\hline Severe anxiety & 5 & 14.3 & 1.0 & 5.9 \\
\hline Total & 35 & 100 & 17 & 100 \\
\hline \multicolumn{5}{|l|}{ After } \\
\hline No anxiety & 23 & 65.7 & 5 & 29.4 \\
\hline Mild anxiety & 11 & 31.4 & 11 & 64.7 \\
\hline Moderate anxiety & 0 & 0.0 & 1 & 5.9 \\
\hline severe anxiety & 0 & 0.0 & 0 & 0.0 \\
\hline Extremely severe anxiety & 1 & 2.9 & 0 & 0.0 \\
\hline Total & 35 & 100 & 17 & 100 \\
\hline
\end{tabular}

Table 2 shows the mean of pain in the therapy group before the hypno-EFT was 3.20, the median was 3.00 and standard deviation was 1.91. The minimum value of pain was 0 and maximum value was 9 . At the $95 \%$ level of confidence, the respondent got the pain at 2.55 -.3 .85 . While after intervention, the averages was 1.54, median was 1.00 and standard deviation was 1.597 . The minimum value of pain was 0 and maximum value was 6 . At the 95\% level of confidence, the respondent got the pain 0.99 - 2.09. While Wilcoxon signed rank test as shown in the Table 3 showed that p-value $0.000(<0.05)$, which indicated that there was a statistically significant effect of hypno-EFT to decrease of anxiety and pain on treatment group compared to control group. 
Table 2 Descriptive statistics distribution of respondent's pain before and after hypno-EFT therapy during venous blood sampling

\begin{tabular}{lcc}
\hline Pain & & Group \\
\hline Before & Treatment & Control \\
\hline Mean & 3.20 & 1.47 \\
Median & 3.00 & 1.00 \\
Standard of Deviation & 1.91 & 1.87 \\
Min - Max & $0-9$ & $0-8$ \\
95\% CI & $2.55-3.85$ & $0.54-2.40$ \\
\hline After & & \\
\hline Mean & 1.54 & 1.35 \\
Median & 1.00 & 1.00 \\
Standard Deviation & 1.595 & 1.367 \\
Min - Max & $0-6$ & $0-6$ \\
95\% CI & $0.99-2.09$ & $0.65-2.06$ \\
\hline
\end{tabular}

Table 3 Effect of Hypno-EFT in reducing the anxiety and pain by wilcoxon signed rank test

\begin{tabular}{ll}
\hline Anxiety & p-value \\
\hline Treatment group & \\
Pre Test & $0.000^{*}$ \\
Post Test & \\
\hline Control group & 0.083 \\
Pre test & \\
Post Test & \\
\hline Pain & $0.000^{*}$ \\
\hline Treatment group & \\
Pre Test & \\
Post Test & 1.000 \\
\hline Control group & \\
Pre Test & \\
Post Test &
\end{tabular}

Multivariate test was done by the result of four test show value $\mathrm{F}=8.087$ with $\mathrm{p}$-value $=$ 0.001 . According to four different tests it can be concluded that there is a significant effect of the independent variables to the dependent variables. The further test in table 4 showed that there was significant effect of hypno-EFT method to lower the anxiety with $\mathrm{p}$-value $=$ $0.001 \quad(<0.05)$ And also was affected to decrease of pain with $\mathrm{p}$-value $=0.003(<0.05)$.

Table 4 Tests of Between subjects Effects

\begin{tabular}{llcll}
\hline \multicolumn{1}{c}{ Source } & $\begin{array}{c}\text { Dependent } \\
\text { Variable }\end{array}$ & $\begin{array}{c}\text { Type II sum of } \\
\text { squares }\end{array}$ & Mean square & p-value \\
\hline Corrected Model & Anxiety & 616.94 & 616.94 & 0.001 \\
& Pain & 34.22 & 34.22 & 0.003 \\
\hline Group & Anxiety & 616.94 & 616.94 & $0.001^{*}$ \\
& Pain & 34.22 & 34.22 & $0.003^{*}$ \\
\hline Total & Anxiety & 23551.00 & & \\
& Pain & 571.00 & & \\
\hline Corrected Total & Anxiety & 2870.827 & & \\
& Pain & 210.058 & & \\
\hline
\end{tabular}




\section{DISCUSSION}

\section{Anxiety}

Findings showed that there was a significant reduction of anxiety after given hypno-EFT, which shows that 23 people $(65.7 \%)$ with no anxiety, 11 people $(31.4 \%)$ with moderate anxiety, and 1 person (2.9\%) with severe anxiety. According to Ali FM, et all showed that $13.95 \%$ adult got fear or phobia to syringe needle. Moreover, study said that there was another fear to get infectious diseases after using former syringe, scared of blood, scared of pain, and scared to get accidently sample exchanged (Prodia, 2016). In addition, there are several complications of venous blood sampling (Booth et al., 2009). One of them is fainting. It is occurs due to the lack of blood flow to brain. It caused a low blood volume, heartbeat fast and anxiety due to emotional factors (Boonstra, Schiphorst Preuper, Balk, \& Stewart, 2014).

Hypnosis is a way of changing the condition of normal state to hypnosis state. This process was done by changing the external focus to internal focus. Humans were more suggestive at hypnosis conditions, so they can accept suggestions that can be turn into new values (Nurindra, 2007). EFT is a meridian energy therapy such as acupuncture. EFT works directly on the body's meridian system. As well as using a needle, EFT could stimulate the main meridian point by tapping it. Imagine that meridian is like river flow. Emotional or physical problems are the same as river flow inhibitors. The point at the meridian sends kinetic energy to the system energy and release the obstacles that block the flow of energy (Iskandar, 2010).

The research used hypno-EFT technique. It was performed only at the pre-induction stage and then continued with verbal suggestive EFT technique. There are several requirements in this process. As an example, respondents should have a willingness as volunteer, able to communicate and have the ability to focus. The result was respondent's anxiety decreased, but one respondent was in severe anxiety, which was caused by the respondent who was not convinced by hypno-EFT therapy and had small veins.

\section{Pain}

Results of this study also showed that there was a significant decrease of pain after given hypno-EFT, which found that the average of pain was 1.54 , the median was 1.00 and standard of deviation was 1.597 , with the minimum value of pain was 0 and 6 for maximum. According to Boonstra, et all (2014) the range value on VAS for measuring the pain is $\leq 3.4$ as mild pain, 3.5-7.4 as moderate pain and $\geq 7.5$ as severe pain. Based on this category it can be concluded that the average pain of respondent was mild pain. The range of pain was mild pain to severe pain (Boonstra et al., 2014).

This result was appropriate to early study in medical labolatory technology of palembang indicated that $34 \%$ of students got pain during venous blood sampling. The average of pain of respondent was decreased, but, there were 4 people $(11.42 \%)$ had increased pain and anxiety, which is caused by small veins, a deep veinpuncture and nervousness during blood sampling.

\section{Effect of Hypno-EFT in reducing anxiety and pain}

The statistical result obtained p-value of 0.001 $(<0.05)$ for anxiety, and $0.003(<0.05)$ for pain level, which indicated that there was a significant effect of hypno-EFT in decreasing the anxiety and pain during venous blood sampling. These results were in line with previous study who found the therapeutic benefits of EFT (Emotional freedom techniques) therapy (Prameswari \& Ariyani, 2015). Other studies also showed that 50.91\% respondents got severe anxiety during tooth removing. It because people are afraid of syringe and related tools. EFT had an effect on decreasing anxiety in pre-surgery patients (Yahya, 2015). Another study also showed that there was an effect of hypnoteraphy to derease stress levels in psychosomatic gastritis patients (Marthaningtyas, 2012). This result was also in line with previous study that there was effect of hypnoteraphy in decreasing anxiety and pain 
in post-surgery patients (SUMARWANTO, 2015), and also an effect of hypnoteraphy with a combination of analgesic in decreasing pain in post-sectio caesarea patient (Niraski, 2015). Moreover, EFT could reduce the pain in patient of post fremur fracture surgery (Mudatsyir, 2012). In principle, $88 \%$ of human behavior is influenced by the subconscious. New values can be implanted with hypnotherapy and energy balancing by the EFT method. In this process, the suggestions were given to the respondents to relax and feel comfort, which is purposely to decrease the pain during venous blood sampling.

\section{CONCLUSION}

It can be concluded that there were significant effects of Hypno-EFT therapy to decrease the anxiety and pain during venous blood sampling. This method is recommended as an alternative procedure in venous blood sampling with complicating factors.

\section{REFERENCES}

Boonstra, A. M., Schiphorst Preuper, H. R., Balk, G. A., \& Stewart, R. E. (2014). Cut-off points for mild, moderate, and severe pain on the visual analogue scale for pain in patients with chronic musculoskeletal pain. Pain, 155(12), 25452550. doi:10.1016/j.pain.2014.09.014

Booth, K. A., Wallace, A., \& Fitzgerald, D. T. (2009). Phlebotomy for Health Care Personnel: McGraw Hill.

Iskandar, E. (2010). The Miracle of Touch. Bandung: Qanita.

Kuzma, J. W., \& Bohnenblust, S. E. (1992). Basic statistics for the health sciences: Mayfield Mountain View, CA.

Marthaningtyas, S. S. (2012). Pengaruh Hipnoterapi Terhadap Penurunan Tingkat Stres Pada Penderita Gastritis Psikosomatis. Universitas Muhammadiyah Surakarta, Surakarta.

Mudatsyir, M., Heru Purbo, and Tavaria Sundari. (2012). SPIRITUAL EMOTIONAL FREEDOM TECHNIQUE DAN NYERI PASIEN PASCA OPERASI FRAKTUR FEMUR. Interest: Jurnal Ilmu Kesehatan, 1(1).

Niraski, V. (2015). PENGARUH HIPNOTERAPI TERHADAP TINGKAT NYERI PADA IBU POST SECTIO CAESAREA DI RSB JEUMPA PONTIANAK TAHUN 2015. ProNers, 3(1).
Nurindra, Y. (2007). Fundamental hypnosis. IBH. Jakarta.

Nursalam. (2008). Konsep dan penerapan metodologi penelitian ilmu keperawatan: pedoman skripsi, tesis, dan instrumen penelitian keperawatan: Salemba Medika.

Pendergraph, G. E., \& Pendergraph, C. B. (1998). Handbook of phlebotomy and patient service techniques: Lippincott Williams \& Wilkins.

Prameswari, A., \& Ariyani, H. (2015). EMOTIONAL FREEDOM TECHNIQUE (EFT) TERAPI ALTERNATIF UNTUK MENGURANGI KECEMASAN PADA PASIEN YANG AKAN MENJALANI PERCUTANEOUS CORONARY THERAPY (PCI). Jurnal Kedokteran dan Kesehatan Indonesia, 11(1).

Prodia. (2016). Pengambilan Darah Tanpa Rasa Takut. Retrieved

from http://www.prodia.co.id/id/InfoKesehatan/Artik elKesehatanDetails/pengambilan-darah-tanparasa-takut

Stuart, G. W., \& Sundeen, S. J. (2007). Buku saku keperawatan jiwa. Jakarta: EGC.

SUMARWANTO, S. F. A. (2015). PENGARUH HIPNOTERAPI TERHADAP PENURUNAN INTENSITAS NYERI PADA PASIEN POST OPERASI DENGAN SKALA NYERI SEDANG-BERAT DI RUMAH SAKIT BHAYANGKARA POLDA KALBAR TAHUN 2015. ProNers, 3(1).

Temple, G. P., \& Mollon, P. (2011). Reducing anxiety in dental patients using emotional freedom techniques (EFT): a pilot study. Energy Psychol Theory Res Treat, 3, 53-56.

van der Watt, G., Laugharne, J., \& Janca, A. (2008). Complementary and alternative medicine in the treatment of anxiety and depression. Current Opinion in Psychiatry, 21(1), 37-42.

Yahya, K. Y. (2015). PENGARUH TERAPI EMOTIONAL FREEDOM TECHNIQUE TERHADAP PENURUNAN TINGKAT KECEMASAN PASIEN PRE OPERASI DI RUANG BEDAH RSUD PANEMBAHAN SENOPATI BANTUL YOGYAKARTA. STIKES Jenderal A. Yani, Yogyakarta.

Yudiyanta, N. K., \& Novitasari, R. W. (2015). Assessment Nyeri. Jurnal CDK, 226.

Cite this article as: Navianti, D., Garini, A., Karneli. (2018). The reduction of anxiety and pain during venous blood sampling using hypno-eft (emotional freedom techniques) method. Public Health of Indonesia, 4(2):67-72. 